\title{
MOTIVASI PETANI DALAM MENGELOLA HUTAN RAKYAT DI DESA SUKOHARJO 1 KECAMATAN SUKOHARJO KABUPATEN PRINGSEWU
}

\section{(FARMER MOTIVATION IN MANAGING THE PRIVATE FORESTS OF SUKOHARJO 1 VILLAGE SUKOHARJO DISTRICT PRINGSEWU REGENCY)}

\author{
Insani Fahma Nurdina ${ }^{1)}$, Asihing Kustanti' ${ }^{2)}$, dan Rudi Hilmanto ${ }^{2)}$ \\ ${ }^{1)}$ Mahasiswa Jurusan Kehutanan Fakultas Pertanian Universitas Lampung \\ ${ }^{2)}$ Dosen Jurusan Kehutanan Fakultas Pertanian Universitas Lampung \\ Jl. Sumantri Brojonegoro No 1 Bandarlampung. 35145 \\ E-mail: insanifahmanurdina@gmail.com
}

\begin{abstract}
ABSTRAK
Lampung merupakan salah satu provinsi di Indonesia yang mengalami deforestrasi hutan mencapai 600 ha pertahun (Pusdaling, 2013). Hal tersebut menimbulkan dampak penurunan kualitas dan kuantitas hutan, tidak demikian dengan Desa Sukoharjo 1 Kecamatan Sukoharjo Kabupaten Pringsewu, desa tersebut memiliki hutan rakyat mencapai lebih dari 200 ha. Tujuan penelitian ini adalah untuk mengetahui tingkat motivasi petani dan faktor-faktor yang berpengaruh dalam mengelola hutan rakyat. Penelitian dilakukan pada bulan November 2014 di Desa Sukoharjo 1 Kecamatan Sukoharjo Kabupaten Pringsewu. Populasi dalam penelitian ini adalah Kelompok Tani Ngudi Rukun dengan jumlah 32 petani, metode pengambilan sampel secara sensus. Metode analisis yang digunakan dalam penelitian ini adalah deskripsi kuantitatif, yaitu untuk mengetahui tingkat motivasi petani menggunakan teknik penentuan skala likert, sedangkan untuk mengetahui faktor yang berpengaruh dengan tingkat motivasi petani dalam pengelolaan hutan rakyat menggunakan uji regresi ordinal. Berdasarkan hasil penelitian dapat diketahui bahwa tingkat motivasi petani dalam kategori tinggi $(53,15 \%)$. Faktor yang mempengaruhi tingkat motivasi petani yaitu umur, pendapatan, pengalaman usahatani, pendidikan, kegiatan kelompok tani, kegiatan penyuluhan, dan akses informasi.
\end{abstract}

Kata kunci: pengelolaan hutan rakyat, motivasi petani

\section{ABSTRACT}

Lampung Province is one province in Indonesia has deforestation for about 600 hactare in a year (Pusdaling, 2013). This leads to the decline of the quality and quantity of forest. That condition is inversely of Sukoharjo 1 Village Sukoharjo District Pringsewu Regency, the development in that village more than 200 hectar through the private forest development. The purpose of this research were to know the level of motivation farmers and the factors that influence the motivation farmers in managing private forest. The research was conducted on November 2014 in Sukoharjo 1 Village, Sukoharjo District Pringsewu Regency. The population in this research were the group of Ngudi Rukun with the number of 32 farmers, the method sampling of this research used census. Analysis method which used in this research was descriptive quantitative, it aimed to know the level of farmers' motivation by using the technique of determining likert, while to know the factors of influenced with the level of farmers' motivation in managing forest community used ordinal regression test. Based on the research's' result, it can be known that farmers' motivation are in high category $(53,15 \%)$. The factors which influenced farmers' motivation were age, revenue, farm experience, education, and the activities of farmer groups, extension activities and access of the information.

Key words: private forest management, farmer motivation 


\section{PENDAHULUAN}

Berkurangnya luasan lahan hutan yang terjadi dibeberapa daerah di Indonesia menimbulkan dampak penurunan kualitas dan kuantitas hutan. Lampung merupakan salah satu provinsi di Indonesia yang mengalami pengurangan luasan hutan (Pusdaling, 2013). Tidak demikian dengan Desa Sukoharjo 1 Kecamatan Sukoharjo Kabupaten Pringsewu, desa ini memiliki hutan rakyat dengan sistem agroforestri dan agrosilvofisheri mencapai lebih dari 200 ha. Pengelolaan hutan rakyat dengan sistem agroforestri maupun agrosilvofisheri bertujuan untuk mendapatkan hasil yang bervariasi dengan luas lahan yang relatif sempit. Sistem agroforestri akan memproduksi hasil pertanian dan hasil kehutanan secara bergantian.

Pengelolaan tersebut tentu memiliki motivasi tertentu, faktor-faktor yang mempengaruhi motivasi ada dua yaitu faktor internal adalah faktor-faktor yang ada di dalam diri seseorang meliputi umur, tingkat pendapatan, pendidikan, dan pengalaman usahatani dan eksternal adalah faktor-faktor yang ada di luar aspek individu (Clegg, 2001), meliputi kelompok tani hutan rakyat, kegiatan penyuluhan, tingkat kemudahan pemasaran dan akses informasi. Oleh karena itu penelitian ini dilakukan untuk mengetahui secara jelas tingkat motivasi dan faktor-faktor yang menjadi pengaruh motivasi masyarakat desa tersebut dalam mengelola hutan rakyat. Tujuan penelitian ini untuk mengetahui tingkat motivasi petani dan untuk mengetahui faktor-faktor yang mempengaruhi motivasi petani dalam mengelola hutan rakyat.

\section{METODOLOGI PENELITIAN}

Lokasi penelitian dilaksanakan di Desa Sukoharjo 1 Kecamatan Sukoharjo Kabupaten Pringsewu. Penelitian ini dilaksanakan pada bulan November 2014. Alat bantu yang digunakan dalam penelitian ini adalah alat tulis dan komputer, dan objek pada penelitian ini adalah petani hutan rakyat Desa Sukoharjo 1 Kecamatan Sukoharjo Kabupaten Pringsewu.

Penelitian ini terdiri dari 2 data, yaitu data primer diperoleh melalui wawancara secara langsung dengan menggunakan kuisioner mengenai motivasi petani dan faktor yang mempengaruhi motivasi petani dalam pengelolaan hutan rakyat seperti, umur, pendapatan, pendidikan, pengalaman usaha tani, intensitas mengikuti kelompok tani, intensitas mengikuti penyuluhan, dan akses informasi. Sedangkan data sekunder diperoleh dari dinas atau instansi terkait dan lembaga desa berupa gambaran umum lokasi penelitian, serta referensi yang diambil dari teori-teori pendukung analisa penelitian ini.

Populasi untuk penelitian ini adalah petani anggota Kelompok Tani Hutan Rakyat Ngudi Rukun di Desa Sukoharjo 1, Kecamatan Sukoharjo, Kabupaten Pringsewu. Metode pengambilan responden dilakukan dengan teknik sensus sebanyak 32 petani hutan rakyat. Menurut Arikunto (2006) di dalam pengambilan sampel apabila subyek penelitian kurang dari 100 maka diambil semua sehingga penelitian dapat disebut penelitian populasi. Pengolahan dan analisis data dilaksanakan secara deskriptif kuantitatif menggunakan analisis statistik yaitu regresi ordinal. Analisis regresi logistik ordinal merupakan salah satu metode statistik yang menggambarkan hubungan antara suatu variabel respon (Y) dengan lebih dari satu variabel prediktor $(\mathrm{X})$ dimana variabel respon lebih dari dua kategori dan skala pengukuran bersifat tingkatan (Hosmer dan Lemeshow, 2000). Fungsi persamaan regresi logistik ordinal menurut Pindyck dan Rubinfeld (1997) sebagai berikut:

$$
P(Y \leq i / x i)=\frac{e(A)}{1+e \overline{(A)}}
$$


Variabel yang diukur adalah variabel $\mathrm{X}$ (umur, pendapatan, pengalaman berusahatani, pendidikan, kelompok tani, penyuluhan, akses informasi) yang diuji hubungannya dan pengaruhnya dengan variabel Y (motivasi petani).

\section{HASIL DAN PEMBAHASAN}

Pengelolaan hutan rakyat di Desa Sukoharjo 1 dikelola dengan sistem agroforestri murni dan agroforestri dengan campuran lahan perikanan, yang disebut dengan sistem agrosilvofisheri. Menurut Hairiah dkk (2004) sistem agroforestri merupakan sistem pengelolaan sumber daya alam yang dinamis dan berbasis ekologi, dengan mamadukan berbagai jenis pohon pada tingkat lahan (petak) pertanian maupun pada suatu bentang lahan.

Jenis tanaman kehutanan yang ditanam di desa ini adalah jati (Tectona grandis), akasia (Acacia auriculiformis), mahoni (Swietenia mahagoni), sengon (Paraserianthes falcafaria), sedangkan tanaman pertanian adalah kopi (coffea robusta), kakau (Theobroma cacao L), cengkeh (Syzygium aromaticum), melinjo (Gnetum gnemon), petai (Parkia speciosa), jengkol (Pithecollobium lobatum), karet (Hevea brasiliensis). Pemilihan jenis tanaman kehutanan yang diusahakan oleh petani didasarkan pada tanaman yang cepat tumbuh (fast growing) sehingga petani cepat mendapatkan hasilnya, selain itu juga tanaman yang mudah penjualannya dan mudah memperoleh bibit. Petani Desa Sukoharjo 1 memilih sistem agroforestri karena kepemilikan lahan relatif sempit. Hal tersebut dikaji melalui beberapa pertanyaan yang dicantumkan pada kuisioner mengenai motivasi petani dan faktor-faktor yang mempengaruhi petani dalam pengelolaan hutan rakyat.

\section{Motivasi Petani Hutan Rakyat}

Tingkat motivasi diukur dari manfaat hutan rakyat yang dirasakan petani, persepsi petani terhadap hutan rakyat, dan tujuan dalam pengelolaan hutan rakyat dengan teknik penentuan skala likert. Petani hutan rakyat menganggap bahwa hutan rakyat memiliki manfaat tidak hanya berupa materi tetapi juga memiliki manfaat dalam pelestarian lingkungan. Begitu pula dengan persepsi petani bahwa hutan rakyat yang dikelola dengan baik dapat menghasilkan kualitas lingkungan yang baik pula, sehingga petani merasa jika pengelolaan hutan rakyat dihentikan akan berdampak buruk bagi lingkungan sekitar. Beberapa petani $(40,63 \%)$ memiliki tujuan pengelolaan hutan rakyat hanya untuk memenuhi kebutuhan hidup sehari-hari, namun sebagian lainnya $(59,37 \%)$ memilih untuk berinvestasi dalam pengembangan pengelolaan hutan rakyat secara terus-menerus. Witantriasti (2010) mengatakan motivasi yang menjadi pendorong petani dalam berusaha tani hutan rakyat adalah manfaat dan keuntungan relatif yang diperoleh serta tujuan terhadap aktivitas usahatani menjadi tinggi, sedang dan rendah. Berikut hasil penelitian mengenai tingkat motivasi petani hutan rakyat.

Tabel 1. Tingkat motivasi petani hutan rakyat Desa Sukoharjo 1.

\begin{tabular}{crr}
\hline Klasifikasi & Jumlah Responden & Persentase (\%) \\
\hline Rendah & 6 & 18,75 \\
Sedang & 9 & 28,10 \\
Tinggi & 17 & 53,15 \\
Jumlah & 32 & 100 \\
\hline
\end{tabular}

Sumber: Data Primer diolah (2014)

Berdasarkan tabel 1 menunjukan bahwa motivasi petani Desa Sukoharjo 1 dalam mengelola hutan rakyat dalam klasifikasi tinggi sebesar 53,15\%. Hal ini berarti lebih dari 
setengah jumlah petani telah mengelola hutan rakyat dengan baik dan sesuai dengan target dan sasaran petani dalam pengelolaan hutan rakyat. Sehingga telah banyak perkembangan yang dirasakan oleh petani dalam mengembangkan pengelolaan hutan rakyat, baik perkembangan wawasan petani mengenai hutan rakyat maupun perkembangan hasil produksi hutan. Hal ini sesuai dengan yang dikemukakan oleh Thoha (1986) bahwa motivasi menyebabkan seseorang terdorong dalam mencapai tujuan, baik dalam keadaan sadar maupun tidak.

Motivasi petani diketahui dari manfaat hutan rakyat yang diterima oleh petani. Menurut Taufik (2014) manfaat pengembangan hutan rakyat dapat dirasakan dalam jangka panjang, disamping itu banyak manfaat lain, terutama manfaat non material dari aspek pelestarian fungsi lingkungan yang tidak dirasakan secara langsung oleh petani. Petani hutan rakyat Desa Sukoharjo 1 mengaku bahwa manfaat yang diterima tidak hanya berupa pendapatan dari hasil produksi hutan saja, tetapi juga manfaat secara ekologis. Menurut Djajapertjunda (2003) hutan rakyat memiliki manfaat secara ekologis yaitu sebagai sistem penyanggah kehidupan masyarakat dengan mengatur tata air, mencegah banjir, erosi dan sebagai prasarana untuk memelihara kualitas lingkungan hidup.

Persepsi petani Desa Sukoharjo 1 terhadap hutan rakyat yang dirasakan yakni hutan rakyat memberi dampak yang baik bagi kelestarian alam setempat, sehingga motivasi petani untuk mengelola hutan rakyat tetap terjaga. Sejalan dengan penelitian oleh Witantriasti (2010) semakin baik persepsi seseorang terhadap pembangunan hutan rakyat maka semakin baik juga pengelolaan hutan rakyat. Hal ini disebabkan oleh adanya kebutuhan hidup yang harus terpenuhi, dengan dibangunnya hutan rakyat maka petani bisa menjual hasil produksi atau digunakan untuk konsumsi sendiri. Dengan sistem agroforestri hasil yang didapat semakin banyak dan petani memiliki pendapatan dari hutan rakyat secara berkelanjutan.

\section{Deskripsi variabel-variabel yang berhubungan dengan motivasi petani dalam pengelolaan hutan rakyat}

Tingkat motivasi petani dipengaruhi oleh beberapa faktor, baik faktor internal maupun faktor eksternal. Faktor internal merupakan faktor yang berasal dari diri seseorang (Maslow, 1993). Setiap variabel sebaran responden dibagi menjadi 3 kategori, yaitu tinggi, sedang dan rendah. Berikut sebaran responden disajikan pada tabel 2.

Tabel 2. Sebaran responden berdasarkan faktor internal petani hutan rakyat Desa Sukoharjo.

\begin{tabular}{lccrr}
\hline \multicolumn{1}{c}{ Faktor Internal } & Interval & Klasifikasi & $\begin{array}{c}\text { Jumlah } \\
\text { Responden }\end{array}$ & Persentase (\%) \\
\hline Umur & $<15$ tanun & Rendah & 0 & 0 \\
& $15-65$ tahun & Sedang & 32 & 100 \\
& $>65$ tahun & Tinggi & 0 & 0 \\
\hline Jumlah & & & 32 & 100 \\
\hline Pendapatan & $<1$ juta & Rendah & 3 & 9,5 \\
& $1-3,5$ juta & Sedang & 23 & 71,9 \\
& $3,5-6$ juta & Tinggi & 6 & 18,7 \\
\hline Jumlah & & & 32 & 100 \\
\hline Lama Pengalaman Usahatani & $2-12$ tahun & Rendah & 24 & 75 \\
& $13-22$ tahun & Sedang & 6 & 18,7 \\
& $23-32$ tahun & Tinggi & 2 & 6,3 \\
\hline Jumlah & & & 32 & 100 \\
\hline Pendidikan & SD & Rendah & 3 & 9,37 \\
& SMP & Sedang & 9 & 28,13 \\
& SMA & Tinggi & 20 & 62,5 \\
\hline Jumlah & & & 32 & 100 \\
\hline
\end{tabular}

Sumber: Data Primer diolah (2014) 
Berdasarkan tabel 2 menunjukan bahwa semua umur petani hutan rakyat di Desa Sukoharjo 1 masuk dalam kategori sedang, yaitu 15-65 tahun, karena rentang umur petani hutan rakyat berkisar antara 32 sampai 65 tahun. Menurut Tjiptoherijanto (2001) umur produktif adalah kisaran 15 sampai 65 tahun, hal ini dikarenakan umur tersebut memiliki kecenderungan dalam meningkatkan kesejahteraan. Petani hutan rakyat di desa ini tergolong dalam usia muda, karena pengelolaan hutan rakyat bersifat turun temurun, sehingga petani yang sudah tua biasanya digantikan oleh anaknya dalam pelaksanaan pengelolaan hutan rakyat.

Pendapatan petani yang termasuk dalam klasifikasi tinggi mencapai 18,7\%, berkisar antara 3,5 juta sampai 6 juta/bulan/0,25ha. Petani hutan rakyat yang masuk dalam klasifikasi tinggi mengembangkan agrosilvofisheri. Ikan yang dibudidayakan adalah ikan nila, ikan emas, dan ikan gurame, dengan nilai jual yang cukup tinggi. Budidaya ikan dapat memberi kontribusi kepada petani hutan rakyat. Jika dibandingkan dengan UMP (Upah Minimum Propinsi) Lampung, maka petani telah memiliki pendapatan yang sesuai dan lebih tinggi dari UMP. Upah Minimum dalam Permen no.1 Th. 1999 Pasal 1 ayat 1 adalah upah bulanan terendah yang terdiri dari upah pokok termasuk tunjangan tetap. Upah ini berfungsi sebagai jaring pengaman, ditetapkan melalui Keputusan Gubernur berdasarkan rekomendasi dari Dewan Pengupahan. Pada tahun 2015 Upah Minimum Propinsi Lampung sebesar Rp 1.581.000. Sedangkan sebanyak 3 petani yang memiliki pendapatan $<1$ juta/bulan/0,25ha atau yang termasuk dalam kategori rendah adalah petani yang tidak memiliki lahan perikanan ataupun memiliki pekerjaan sampingan. Sejalan dengan penelitian Danhartani dkk (2012) bahwa rendahnya tingkat pendapatan petani menujukkan rendahnya tingkat kesejahteraan petani pula, hal tersebut disebabkan karena pemahaman terhadap perubahan teknologi dan keterampilan yang masih rendah.

Petani hutan rakyat masih tergolong baru dalam mengembangkan hutan rakyat. Dari 32 responden, 75\% merupakan petani yang baru mengelola hutan rakyat selama kurun waktu 212 tahun. Petani yang tergolong baru merupakan petani baru menggantikan orang tuanya dalam mengelola hutan rakyat, sehingga petani hanya memperdalam pengalaman dalam pengelolaan hutan rakyat dengan belajar dari pengalaman orang tua. Petani yang memiliki pengalaman 23-32 tahun atau yang termasuk dalam klasifikasi tinggi hanya sebanyak 6,3\%. Petani yang telah lama berpengalaman dalam pengelolaan hutan rakyat mengangap bahwa bertani merupakan cara hidupnya yang paling baik dan sesuai untuk diri petani. Mubyarto (2000) menjelaskan bahwa pengalaman dan kemampuan bertani yang telah dimiliki sejak lama merupakan cara hidup (way of life) yang memberikan keuntungan petani.

Tingkat pendidikan formal petani hutan rakyat di Desa Sukoharjo 1 dengan persentase 62,5\% adalah tingkat Sekolah Menengah Atas, hal itu berarti bahwa petani telah melewati kewajiban melaksanakan wajib belajar 9 tahun. Program wajib belajar 9 tahun ini diharapkan dapat mengembangkan dan membawa dampak kemajuan bagi masyarakat Indonesia dan dapat direalisasikan secara merata sampai ke seluruh daerah-daerah di Indonesia mulai dari kota-kota besar hingga daerah-daerah terpencil sekalipun (Sudibyo, 2008). Kemudian persentase 28,13\% adalah petani dengan tingkat pendidikan Sekolah Menengah Pertama (SMP) dan 9,37\% adalah petani dengan tingkat pendidikan Sekolah Dasar (SD). Terdapat beberapa alasan petani tidak melanjutkan tingkat pendidikan formal, salah satunya yaitu berkurangnya minat petani karena pada dasarnya berasal dari keluarga petani yang telah memiliki penghasilan dari produksi lahan agroforestri sehingga kurang memikirkan pendidikan.

Selain faktor internal terdapat pula faktor eksternal yang dapat mempengaruhi tingkat motivasi petani. Faktor eksternal adalah faktor yang berasal dari luar diri seseorang (Maslow, 1993). Berikut sebaran responden berdasarkan faktor eksternal yang mempengaruhi tingkat motivasi. 
Tabel 3. Sebaran responden berdasarkan faktor eksternal petani hutan rakyat Desa Sukoharjo 1.

\begin{tabular}{|c|c|c|c|c|}
\hline Faktor Eksternal & Interval & Klasifikasi & Jumlah Responden & Persentase (\%) \\
\hline \multirow[t]{3}{*}{ Kegiatan kelompok tani } & $1-3 \mathrm{kali} /$ tahun & Rendah & 1 & 3,13 \\
\hline & 4-6 kali/tahun & Sedang & 3 & 9,37 \\
\hline & 7-9 kali/tahun & Tinggi & 28 & 87,5 \\
\hline Jumlah & & & 32 & 100 \\
\hline \multirow[t]{3}{*}{ Kegiatan penyuluhan } & 4 kali/tahun & Rendah & 16 & 50.0 \\
\hline & $5 \mathrm{kali} /$ tahun & Sedang & 11 & 34,38 \\
\hline & $6 \mathrm{kali} /$ tahun & Tinggi & 5 & 15,62 \\
\hline Jumlah & & & 32 & 100 \\
\hline \multirow[t]{3}{*}{ Akses informasi } & Sulit & Rendah & 4 & 12,5 \\
\hline & Sedang & Sedang & 11 & 34,38 \\
\hline & Mudah & Tinggi & 17 & 53,12 \\
\hline Jumlah & & & 32 & 100 \\
\hline
\end{tabular}

Sumber: Data Primer diolah (2014)

Berdasarkan tabel 3 di atas menunjukan intensitas mengikuti kegiatan kelompok tani hutan rakyat oleh petani dalam klasifikasi tinggi, yaitu sebanyak 28 responden, merasakan manfaat dari keberadaan kelompok tani tersebut, dikarenakan petani dapat saling berbagi pengalaman dalam pengelolaan hutan rakyat lebih baik lagi. Sesuai dengan yang dikemukakan oleh Abbas (1995) bahwa kerjasama antara individu anggota kelompok dalam proses belajar, proses berproduksi, pengolahan hasil dan pemasaran hasil untuk peningkatan pendapatan dan kehidupan yang layak dapat dijalin melalui pendekatan kelompok. Kegiatan Kelompok Tani Ngudi Rukun merupakan kegiatan rutin yang dilakukan setiap bulannya, adapun kegiatan tersebut antara lain pemeliharaan Cek Dam Ngudi Rukun, yaitu Unit Percontohan Penyuluh Kehutanan, pembuatan kolam bibit ikan, diskusi terbuka berkaitan dengan pengelolaan hutan rakyat, dan berbagai kegiatan antar Kelompok Tani di Desa Sukoharjo 1.

Nasution (2005) menjelaskan bahwa penyuluhan merupakan pendidikan dalam pemecahan masalah yang berorientasi pada tindakan untuk mengajarkan sesuatu, mendemonstrasikan, memotivasi tetapi tidak melaksanakan program yang non edukatif. Hasil penelitian menunjukkan bahwa frekuensi paling kecil petani dalam mengikuti kegiatan penyuluhan sebanyak 4 kali pertemuan dalam setahun, hal tersebut mengasumsikan bahwa kegiatan penyuluhan kurang menarik perhatian petani dibanding dengan kegiatan kelompok tani. Namun hanya sebanyak $15,62 \%$ petani termasuk kedalam frekuensi tinggi, mengikuti kegiatan penyuluhan 6 kali pertemuan dalam 1 tahun terakhir, karena dalam 1 tahun terakhir terdapat 6 kali kegiatan penyuluhan yang diadakan baik dari dinas, maupun dari penyuluh Badan Penyuluh Pertanian dan Kehutanan (BP3K) serta Badan Penyuluh Pertanian Perikanan Peternakan dan Kehutanan (BP4K). Kurang minatnya petani dikarenakan sulitnya menerima informasi yang disampaikan oleh penyuluh, biasanya informasi yang diberikan bersifat inovatif, yaitu teknologi baru yang masih banyak petani tidak bisa menerima informasi tersebut, sehingga petani lebih memilih untuk rutin dalam kegiatan kelompok tani dimana petani lebih mudah dan sudah terbiasa untuk saling tukar pengalaman.

Dilihat dari tabel 3 di atas, bahwa 53,12\% merupakan petani yang menerima informasi dengan mudah. Hal tersebut menunjukkan bahwa petani dapat dengan mudah menerima informasi baik dari sumber informasi yaitu penyuluh maupun sumber media informasi dari televisi, koran, dan buku-buku pertanian. Macam akses informasi yang diperoleh petani antara lain mengenai wawasan pertanian, wawasan yang berkaitan tentang hutan rakyat, serta informasi dalam mendukung usahatani hutan rakyat. Mosher (1991) berpendapat akses informasi merupakan hal penting untuk meningkatkan perbaikan usahatani hutan rakyat. 


\section{Faktor-Faktor Yang Mempengaruhi Tingkat Motivasi}

Analisis faktor-faktor yang mempengaruhi tingkat motivasi menggunakan uji regresi ordinal. Uji regresi ordinal dipilih karena pengukuran yang dilakukan mengunakan skala ordinal. Berikut hasil uji regresi logistik ordinal.

Tabel 4. Parameter Estimasi.

\begin{tabular}{|c|c|c|c|c|c|}
\hline & & \multirow[b]{3}{*}{ Estimate } & \multirow[b]{3}{*}{ Sig. } & \multicolumn{2}{|c|}{ 95\%Confidence Interval } \\
\hline & & & & Lower & Upper \\
\hline & & & & Bound & Bound \\
\hline \multirow[t]{2}{*}{ Threshold } & $\mathrm{Y}=1.00$ (motivasi rendah) & -2.888 & 0.035 & -5.576 & -0.200 \\
\hline & $Y=2.00$ (motivasi tinggi) & -0.887 & 0.004 & -1.197 & 2.970 \\
\hline \multirow[t]{19}{*}{ Location } & $x_{1}($ umur $15-65)$ & -0.413 & 0.023 & -2.634 & 1.808 \\
\hline & $x_{2}($ pendapatan $<1$ juta $)$ & 8.393 & 0.108 & -2.188 & 7.403 \\
\hline & $x_{2}$ (pendapatan $1-3,5$ juta $)$ & -0.233 & 0.009 & -1.948 & 1.481 \\
\hline & $x_{2}($ pendapatan 3,5-6juta $)$ & 0.130 & 2.303 & -2.960 & 1.324 \\
\hline & $x_{3}$ (pengalaman 2-12 tahun) & -1.366 & 0.013 & -4.781 & 2.048 \\
\hline & $x_{3}$ (pengalaman 13-22 tahun) & 0.065 & 0.445 & -1.774 & 1.904 \\
\hline & $x_{3}$ (pengalaman 23-32 tahun) & 0.963 & 1.368 & 1.947 & 1.947 \\
\hline & $x_{4}($ pendidikan SD $)$ & -1.672 & 0.760 & -1.902 & 1.609 \\
\hline & $x_{4}($ pendidikan SMP) & 1.217 & 0.105 & -1.212 & 1.787 \\
\hline & $x_{4}($ pendidikan SMA) & -0.917 & 0.035 & -3.222 & 1.387 \\
\hline & $x_{5}(\mathrm{keg}$. Kelompok tani $1-3$ kali pertemuan) & 3.719 & 0.127 & 0.257 & 7.181 \\
\hline & $\chi_{5}$ (keg. Kelompok tani 4-6kali pertemuan) & -2.065 & 1.638 & -6.355 & 2.225 \\
\hline & $\chi_{5}$ (keg. Kelompok tani 7-9 kali Pertemuan) & -1.195 & 0.006 & -1.387 & 2.445 \\
\hline & $x_{6}(\mathrm{keg}$. penyuluhan 4 kali pertemuan $)$ & 0.738 & 0.038 & -0.837 & 2.314 \\
\hline & $x_{6}($ keg. Penyuluhan 5 kali pertemuan) & -8.393 & 0.329 & -24.188 & 7.403 \\
\hline & $x_{6}($ keg. Penyuluhan 6 kali pertemuan) & 0.224 & 1.553 & -2.820 & 3.269 \\
\hline & $x_{7}$ (akses informasi rendah) & 0.432 & 2.026 & -3.539 & 4.404 \\
\hline & $x_{7}$ (akses informasi sedang) & 0.226 & 0.183 & -68.324 & 27.872 \\
\hline & $\underline{x}_{z}$ (akses informasi Tinggi) & -1.067 & 0.010 & -0.503 & 2.638 \\
\hline
\end{tabular}

Sumber: Data Primer diolah (2014)

Tabel 4 menunjukan bahwa variabel yang berpengaruh terhadap tingkat motivasi petani dalam mengelola hutan rakyat adalah variabel umur (15-65 tahun), pendapatan (1-3,5juta), pengalaman berusahatani (2-12 tahun), pendidikan (SMA), kegiatan kelompok tani (7-9 kali), kegiatan penyuluhan (4 kali), akses informasi (tinggi) dengan taraf nyata 0,05 (5\%). Sedangkan variabel yang tidak berpengaruh adalah pendapatan $(<1$ dan 3,5-6juta), pengalaman berusahatani (13-22 tahun dan 23-32 tahun), pendidikan (SD dan SMP), kegiatan kelompok tani (1-3 kali dan 4-6 kali), kegiatan penyuluhan (5 kali dan 6 kali), akses informasi (rendah dan sedang). Berdasarkan parameter estimasi tersebut maka bentuk persamaan tingkat motivasi petani hutan rakyat yaitu:

\section{Logit 1}

$\mathrm{g}_{1}(\mathrm{x})=-2,888-0,413\left(x_{1}\right)-0,233\left(x_{2}\right)+0,065\left(x_{3}\right)-0,917\left(x_{4}\right)-1,195\left(x_{5}\right)+0,738\left(x_{6}\right)-1,067\left(x_{7}\right)$ Logit 2

$\mathrm{g}_{1}(\mathrm{x})=-0,887-0,413\left(x_{1}\right)-0,233\left(x_{2}\right)+0,065\left(x_{3}\right)-0,917\left(x_{4}\right)-1,195\left(x_{5}\right)+0,738\left(x_{6}\right)-1,067\left(x_{7}\right)$

Interpretasi:

1. Logit 1 memiliki nilai estimasi sebesar $-2,888$ persamaan ini digunakan untuk tingkat motivasi rendah.

2. Logit 2 memiliki nilai estimasi sebesar 0,887 persamaan ini digunakan untuk tingkat motivasi tinggi. 
Berdasarkan hasil analisis tersebut maka masing-masing faktor yang mempengaruhi tingkat motivasi petani hutan rakyat dapat dijelaskan sebagai berikut:

\section{Umur Petani}

Variabel umur yang berpengaruh dalam pengelolaan hutan rakyat adalah variabel umur petani berkisar antara 15-65 tahun dengan persentase 100\% yaitu sebanyak 32 petani. Umur petani termasuk dalam umur produktif. Umur yang produktif mengindikasikan bahwa petani memiliki kemampuan berfikir yang baik serta kemampuan kerja yang optimal. Menurut Dewandini (2010) menjelaskan bahwa pada umumnya responden yang berusia produktif memiliki semangat yang lebih tinggi, termasuk semangat dalam mengembangkan usahataninya. Berdasarkan wawancara di lapangan, petani yang sudah tua memberikan hak kelola lahan hutan rakyat kepada anaknya karena kondisi fisik yang sudah menurun, sehingga responden petani yang ditemui rata-rata merupakan usia produktif (muda). Robbins (2007) mengemukakan bahwa para pekerja yang sudah tua cenderung kurang luwes dan menolak teknologi baru. Umur berkorelasi dengan produktifitas, produktifitas akan merosot dengan bertambahnya usia seseorang. Nilai koefisien variabel umur memiliki nilai negatif, menunjukan bahwa umur akan menurunkan tingkat motivasi petani hutan rakyat sebesar 0,413 dan berpengaruh nyata. Karena variabel ini memiliki nilai signifikan 0,023 yang artinya bahwa variabel ini berpengaruh nyata terhadap motivasi petani hutan rakyat dengan taraf nyata $\alpha=0,05(5 \%)$.

\section{Pendapatan Petani}

Pendapatan merupakan salah satu motivasi dalam mempertahankan pengelolaan hutan rakyat. Sesuai yang dikemukakan oleh Suprayino dkk (2012) bahwa motivasi untuk tetap mempertahankan keterlibatan dalam pengelolan hutan rakyat adalah mendapat pengakuan kemampuan diri, melestarikan hutan dan pendapatan. Pendapatan petani hutan rakyat terdiri dari hasil pertanian berupa kakau, kopi, karet, petai, jengkol, melinjo, dan cengkeh, hasil kayu berupa jati, mahoni, sengon, dan akasia, serta hasil lahan perikanan berupa ikan nila, ikan emas, dan ikan gurame. Menurut Attar (1999) semakin beraneka ragam tanaman yang ditanam pada sebuah lahan, maka semakin meningkat keanekaragaman vertikal dan horizontalnya. Keanekaragaman vertikal yang dimaksud adalah menyangkut tinggi rendahnya tanaman yang dikelompokkan menjadi pohon, perdu, semak, dan rumput, sedangkan keanakaragaman horizontal menyangkut tanaman hias dan tanaman industri. Bagitu pula yang terjadi di Desa Sukoharjo 1, agroforestri dikelola dengan pola penggabungan tanaman pertanian dan tanaman kehutanan. Beberapa lahan agroforestri memiliki pola tambahan lahan perikanan yang disebut agrosilvofisheri. Pendapatan yang berpengaruh dalam pengelolaan hutan rakyat adalah pendapatan petani dalam interval 1-3,5juta/0,25ha lahan agroforestri perbulan. Menurut Sajogyo (1996) penduduk Indonesia yang berada di atas garis kemiskinan (tidak miskin), bila konsumsi beras sebanyak $>480 \mathrm{~kg} / \mathrm{kapita} / \mathrm{tahun}$. Hal tersebut berarti bahwa petani yang berada diatas garis kemiskinan harus memiliki pendapatan pada setiap bulan sebesar \pm 400.000 ,-/orang, sehingga dapat disimpulkan bahwa petani Desa Sukoharjo 1 berada diatas garis kemiskinan. Nilai koefisien variabel pendapatan ini memiliki tanda negatif, menunjukan bahwa pendapatan petani akan menurunkan motivasi petani hutan rakyat sebesar 0,233. Variabel ini memiliki nilai signifikan 0,009 yang artinya bahwa variabel ini berpengaruh nyata terhadap motivasi petani hutan rakyat dengan taraf nyata $\alpha=0,05$ (5\%). Hal tersebut menunjukkan bahwa petani hutan rakyat yang memiliki pendapatan lebih rendah akan lebih meningkatkan motivasi dalam pengelolaan hutan rakyat, agar dapat meningkatkan penghasilan dalam pengelolaan hutan rakyat. 


\section{Pengalaman Berusahatani}

Pengalaman berusahatani merupakan lamanya petani mengelola hutan rakyat. Petani hutan rakyat Desa Sukoharjo 1 memiliki pengalaman dari 2-34 tahun. Nilai koefisien variabel pengalaman berusahatani ini memiliki tanda negatif, variabel pengalaman ini akan menurunkan tingkat motivasi petani hutan rakyat, yaitu petani yang memiliki pengalaman 212 tahun. Variabel ini memiliki nilai signifikan 0,013 yang artinya bahwa variabel ini berpengaruh nyata terhadap motivasi petani hutan rakyat dengan taraf nyata $\alpha=0,05(5 \%)$. menunjukan bahwa rendahnya pengalaman usaha tani akan berpengaruh pada penurunan tingkat motivasi petani hutan rakyat sebesar 1,366. Berbeda halnya dengan penelitian yang dilakukan oleh Waluyo dkk (2010), bahwa lama pengalaman usaha tani yang termasuk dalam kategori tinggi adalah pengalaman petani $>20$ tahun yang akan berpengaruh pada peningkatan motivasi petani dalam mengelola hutan rakyat. Sedangkan lama pengalaman usaha tani yang berada di Desa Sukoharjo 1 yang berpengaruh pada peningkatan motivasi adalah pengalaman 2-12 tahun, hal ini dikarenakan petani yang menjadi responden penelitian ini merupakan anak dari petani yang sebagian besar melanjutkan usaha tani secara turun temurun.

\section{Pendidikan Petani}

Variabel pendidikan petani hutan rakyat berpengaruh pada tingkat motivasi, sesuai yang dikemukakan oleh Dewandini (2010) bahwa tingkat pendidikan formal dapat mempengaruhi tingkat kecepatan petani dalam menerima suatu teknologi baru. Secara teoritis semakin tinggi tingkat pendidikan seorang petani maka akan semakin cepat pula petani tersebut dapat menerima suatu teknologi baru. Mardikanto dan Rasyid (1996) menambahkan bahwa pendidikan petani mempengaruhi pola pikir petani menjadi lebih dinamis. Hasil uji regresi ordinal menunjukkan variabel pendidikan SMA memiliki nilai signifikan sebesar 0,035 dari taraf nyata $(5 \%)$ yang menjadi pengaruh nyata terhadap tingkat motivasi, yang berarti jika pendidikan formal petani lebih tinggi maka akan berpengaruh pada peningkatan motivasi petani sebesar 0,917 .

\section{Kegiatan Kelompok Tani}

Kegiatan kelompok tani merupakan salah satu variabel yang dapat mempengaruhi motivasi petani hutan rakyat. Variabel yang memiliki nilai signifikan lebih kecil dari taraf nyata adalah intensitas mengikuti kegiatan kelompok tani 7-9 kali pertemuan dengan nilai 0.006. Memiliki nilai koefisien variabel negatif, menunjukan bahwa tingkat intensitas mengikuti kegiatan rutin kelompok tani pada 7-9 kali pertemuan akan menurunkan tingkat motivasi petani hutan rakyat sebesar 2,065. Seperti penelitian yang dilakukan oleh Kushartanti (2001) bahwa tingkat motivasi petani dalam pengelolaan jagung menurun pada intensitas tinggi kegiatan kelompok tani di Kabupaten Semarang, dikarenakan petani mengangap tidak ada dampak yang terjadi dalam pengelolaan setalah mengikuti kegiatan kelompok tani. Berbeda pendapat dengan yang dijelaskan oleh Yumi dkk (2012) bahwasanya kelembagaan merupakan pendukung pembelajaran petani yang mempengaruhi intensitas belajar petani.

\section{Kegiatan Penyuluhan}

Kegiatan penyuluhan merupakan salah satu variabel yang dapat mempengaruhi motivasi petani hutan rakyat, karena penyuluhan merupakan satu kegiatan untuk mengubah perilaku petani, perubahan perilaku sasaran terkait dengan proses adopsi. Adopsi menurut Mulyadi dkk (2007) adalah keputusan untuk memanfaatkan sepenuhnya ide baru/inovasi, dimana keputusan tersebut merupakan pilihan terbaik dari tindakan-tindakan yang dilakukan oleh individu. Masuk dan menyebarnya inovasi baru ke dalam satu sistem sosial atau kelompok tani dimulai dengan pemanfaatan saluran komunikasi yang tepat dalam 
penyampaian inovasi baru. Berdasarkan hasil wawancara di lapangan intensitas mengikuti kegiatan penyuluhan sebanyak 4 kali pertemuan memiliki nilai signifikan 0.038. Nilai tersebut menunjukan bahwa kegiatan penyuluhan memiliki pengaruh nyata terhadap tingkat motivasi. Hasil tersebut berarti bahwa tingkat intensitas mengikuti kegiatan penyuluhan oleh petani akan meningkatkan tingkat motivasi petani hutan rakyat sebesar 0,738 .

\section{Akses Informasi}

Akses informasi akan memberikan pengaruh pada peningkatan pengetahuan petani, khususnya dalam pengelolaan hutan rakyat. Waluyo dkk (2013) mengemukakan bahwa pengetahuan yang baik tentang pengelolaan hutan rakyat merupakan acuan yang baik bagi petani agar progam yang telah direncanakan dapat berjalan. Variabel akses informasi memiliki nilai signifikan sebesar 0,010 dari taraf nyata (5\%) yang berarti akses informasi berpengaruh nyata terhadap tingkat motivasi. Variabel ini memiliki nilai koefisien negatif, yang berarti bahwa akses informasi akan menurunkan tingkat motivasi sebesar 1,067. Hal tersebut membuktikan bahwa mudahnnya akses informasi yang diperoleh oleh petani tidak berarti memberikan peningkatan motivasi dalam pengelolaan hutan rakyat karena petani merasa sulit menerima hal yang baru. Berbeda dengan Andriyati dan Setyorini (2012) yang mengemukakan bahwa akses informasi yang didapatkan oleh petani baik dari sumber informasi maupun sumber media informasi akan memberi pengaruh baik bagi petani dalam kontribusi pemecahan masalah yang dihadapi petani dalam berproduksi. Hal ini sejalan dengan pernyataan Suryantini (2004) bahwa ketersediaan berbagai informasi teknologi pertanian akan mempercepat kemajuan usaha pertanian.

\section{KESIMPULAN DAN SARAN}

\section{Kesimpulan}

Petani hutan rakyat Desa Sukoharjo 1 Kecamatan Sukoharjo Kabupaten Pringsewu yang tergabung dalam kelompok tani Ngudi Rukun memiliki tingkat motivasi tinggi sebesar $53,15 \%$ dalam pengelolalan hutan rakyat. Faktor-faktor yang berpengaruh terhadap tingkat motivasi petani dalam pengelolaan hutan rakyat adalah umur, pendapatan, pengalaman usaha tani, pendidikan, kegiatan kelompok tani, kegiatan penyuluhan dan akses informasi.

\section{Saran}

Perlu dilakukan pelatihan, penyuluhan, dan pembinaan dalam pengelolaan hutan rakyat untuk menghasilkan kualitas serta kuantitas produksi yang tinggi secara terus-menerus kepada seluruh petani hutan dan perlu adanya apresiasi pemerintah terhadap petani untuk meningkatkan motivasi petani dalam mengelola hutan rakyat.

\section{DAFTAR PUSTAKA}

Abbas, S. 1995. 90 Tahun Penyuluhan Pertanian Di Indonesia (1905-1995). Buku. Jakarta: Departemen Pertanian. $90 \mathrm{Hlm}$.

Adrianti, E dan Setyorini, E. 2012. Ketersediaan sumber informasi teknologi pertanian $\quad D i$ beberapa Kabupaten di Jawa. Jurnal Perpustakaan Pertanian. 21(1):30-35.

Arikunto, S. 2006. Prosedur Penelitian Suatu Pendekatan Praktek. Buku. PT Rineka Cipta. Jakarta. 370 Hlm.

Attar M. 1999. Kajian pengelolaan hutan rakyat, kontribusinya terhadap pendapatan rumah tangga petani dan peranannya dalam perekonomian desa. Skripsi. Bogor : Fakultas Kehutanan. Institut Pertanian Bogor. 215 Hlm. 
Clegg, B. 2001. Instan Motivator: 79 Cara Instan Menumbuhkan Motivasi. Buku. Erlangga. Jakarta. $203 \mathrm{Hlm}$.

Danhartani, Radiah, E, dan Hanafie, U. 2012 . Tingkat kesejahteraan buruh tani tanaman pangan di Kecamatan Aluh-aluh Kabupaten Banjar. Jurnal Agribisnis Perdesaan. 2 (3). 193-209.

Dewandini, S. K. 2010. Motivasi petani dalam budidaya tanaman mending di Kecamatan Minggir Kabupaten Sleman. Skripsi. Fakultas Pertanian Universitas Sebelas Maret: Surakarta. $131 \mathrm{Hlm}$.

Djajapertjunda S. 2003. Mengembangkan Hutan Milik di Jawa. Buku. Bandung. Alqaprint Jatinangor. $88 \mathrm{Hlm}$.

Hairiah, K,D. Suprayogo, dan M.V. Noordwijk. 2004. Ketebalan serasah sebagai indikator daerah aliran sungai (DAS) yang sehat. Word Agroforestry Center. Bogor. 4-7.

Hosmer, D.W and S. Lemeshow. 2000. Applied Logistic Regression Second Edition. New York: John Wiley and Sons, Inc.

Kushartanti, E. 2001. Keefektifan media cetak pada diseminasi dan adopsi teknologi jagung bisma di Kabupaten Semarang. Thesis. Program Pasca Sarjana Universitas Gadjah Mada Yogyakarta. $152 \mathrm{Hlm}$.

Mardikanto T, dan Rasyid MA. 1996. Penyuluhan Pembangunan Kehutanan Kerjasama Departemen Kehutanan Dan Fakultas Pertanian Universitas Sebelas Maret Surakarta. Buku. Jakarta: Departemen Kehutanan. 145 Hlm.

Maslow, AH. 1993. Motivasi Dan Kepribadian-1 Seri Manajemen No.104 A. Buku. Jakarta PT. Pustaka Binaman Pressindo. $156 \mathrm{Hlm}$.

Mosher AT. 1991. Menggerakkan dan Membangun Pertanian. Syarat-Syarat Pokok Pembangunan dan Modernisasi. Buku. Jakarta: CV Yasaguna. $330 \mathrm{Hlm}$.

Mubyarto. 2000. Membangun Sistem Ekonomi. Buku. Yogyakarta: BPFE. $319 \mathrm{Hlm}$.

Mulyadi, Basita Ginting Sugihen, Pang S. Asngari, dan Djoko Susanto. 2007. Proses adopsi inovasi pertanian suku pedalaman arfak di Kabupaten Manokwari Papua Barat. Jurnal Penyuluhan. 3 (2). 110-118.

Nasution M. 2005. Metode Penelitian. Buku. Bogor: Ghalia Indonesia. $220 \mathrm{Hlm}$.

Peraturan Menteri Tenaga Kerja Nomor 1 Tahun 1995. Upah minimum propinsi. Jakarta. Kementaker.

Pindiyck, R. S., dan Daniel, L. R. 1997. Economertic Models and Econometric Forecast fourth edition. Irwin Mc Graw-Hill. Boston.

Pusdaling. 2013. Sensus Pertanian Indonesia. Pusat Data Lingkungan. Jakarta.

Robbins SP. 2007. Perilaku Organisasi. Buku. Jakarta. PT Indeks. 256 Hlm.

Sajogyo. 1996. Memahami Dan Menanggulangi Kemiskinan Di Indonesia. Buku. Jakarta. Grasindo. $148 \mathrm{Hlm}$.

Sudibyo, B. 2008. Depdiknas Optimis Target Wajib Belajar 9 Tahun Tuntas Tahun Ini. http://berita.ohapa.com/14/17/44/depdiknas- Mendiknas. Diunduh 21 April 2015.

Suprayino. AR., Sumardjo., Gani. S.D., Sugihen. G. B. 2012. Motivasi dan pertisipasi petani dalam pengelolaan hutan di Kabupaten Maros Provinsi Sulawesi Selatan. Jurnal Penyuluhan. 8 (2). 176-195.

Suryantini, H. 2004. Pemanfaatan informasi teknologi pertanian oleh penyuluh pertanian kasus di Kabupaten Bogor, Jawa Barat. Jurnal Perpustakaan Pertanian. 13 (1).17_ 23.

Taufik, M. 2014. Hutan rakyat: produk proses budaya. World Argoforestry Centre (ICRAF) Indonesia. 7 (1). 13-14.

Thoha. 1986. Prilaku Organisasi. Buku. Grafindo. Jakarta. 327 Hlm. 
Tjiptoherijanto. Prijono. 2001. Proyeksi Penduduk, Angkatan Kerja, TenagaKerja, dan Peran Serikat Pekerja dalam Peningkatan Kesejahteraan. Diakses pada tanggal 16 januari 2014.Pukul 10.00 WIB. Sumber: http//windows.majalah //perencanaan. pembangunan //edisi.23.tahun.2001. Pdf.

Waluyo. A. E., Ulya. A., dan Martin. E., 2013. Perencanaan sosial dala rangka pengembangan hutan rakyat di Sumatera Selatan. Jurnal Penelitian Hutan dan Konservasi Alam. VII (3). 271-280.

Witatriasti, Tantri. 2010. Faktor-Faktor Yang Mempengaruhi Intensitas Pegelolaan Hutan Rakyat Di Desa Gunuug Sari Kecamatan Pamijaha Kabupaten Bogor. Skripsi. Institut Pertanian Bogor: Bogor. 99 Hlm.

Yumi, Sumardjo, Darwis S. G., dan Basita G. S., 2012. Model pengembangan dan pembelajaran petani dalam pengelolaan hutan rakyat lestari. Jurnal Penelitian Sosial dan Ekonomi Kehutanan. 8 (3). 196-210. 